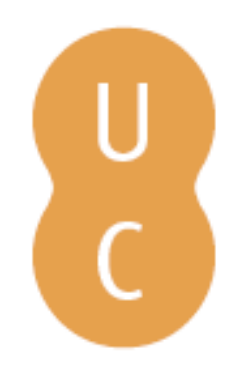

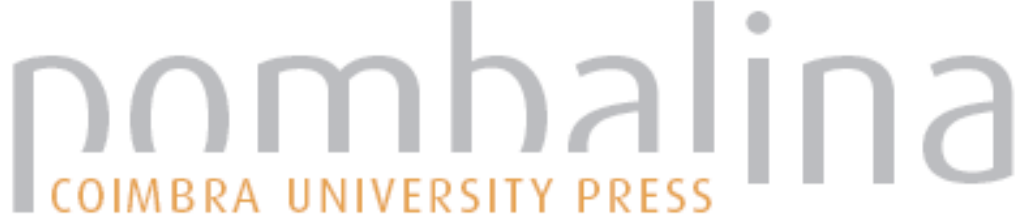

\section{How minerals are important for human health}

Autor(es): $\quad$ Gomes, C. de Sousa Figueiredo

Publicado por: Imprensa da Universidade de Coimbra

URL

persistente: URI:http://hdl.handle.net/10316.2/39234

DOI: $\quad$ DOI:http://dx.doi.org/10.14195/978-989-26-0322-3_27

Accessed : $\quad$ 26-Apr-2023 15:22:02

A navegação consulta e descarregamento dos títulos inseridos nas Bibliotecas Digitais UC Digitalis, UC Pombalina e UC Impactum, pressupõem a aceitação plena e sem reservas dos Termos e Condições de Uso destas Bibliotecas Digitais, disponíveis em https://digitalis.uc.pt/pt-pt/termos.

Conforme exposto nos referidos Termos e Condições de Uso, o descarregamento de títulos de acesso restrito requer uma licença válida de autorização devendo o utilizador aceder ao(s) documento(s) a partir de um endereço de IP da instituição detentora da supramencionada licença.

Ao utilizador é apenas permitido o descarregamento para uso pessoal, pelo que o emprego do(s) título(s) descarregado(s) para outro fim, designadamente comercial, carece de autorização do respetivo autor ou editor da obra.

Na medida em que todas as obras da UC Digitalis se encontram protegidas pelo Código do Direito de Autor e Direitos Conexos e demais legislação aplicável, toda a cópia, parcial ou total, deste documento, nos casos em que é legalmente admitida, deverá conter ou fazer-se acompanhar por este aviso.

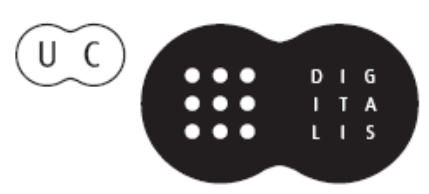


MARTIM PORTUGAL V. FERREIRA

Coordenação

\section{A Geologia de Engenharia e os Recursos Geológicos \\ VOL. 2 - RECURSOS GEOLÓGICOS E FORMAÇÃO}

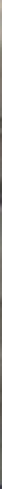




\title{
HOW MINERALS ARE IMPORTANT FOR HUMAN HEALTH
}

\author{
C. de Sousa Figueiredo Gomes ${ }^{1}$
}

KEY WORDS: clay, sand, rock salt, spring water, human health, geomedicine.

PAlavras-CHAVE: argila, areia, sal-gema, água mineromedicinal, saúde humana, geomedicina.

\begin{abstract}
Unfortunately, research in recent years has been mainly addressed to the negative effects of minerals in the human health. However, it is well established that some particular minerals are of paramount importance for good human health, either being part of the composition of drinkable spring waters and eatable vegetables and fruits, or being incorporated in many pharmacs after being submitted to some degree of industrial processing. Presently, there is a growing interest on treatments using natural means, alternative to those of the conventional medicine. It is the so-called naturotherapy, that involves distinct processes and methods, such as: phytotherapy, hydrotherapy, mudtherapy, thermotherapy, etc. Whenever naturotherapy involves minerals or other mineral resources we can name it geomedicine, a scientific area that comprises the fundamentals and practises of the application of geomaterials as conditioners of human health. In fact, particular types of clay/mud, sand, rock salt and spring water, intervene both as chemical and physical conditioners in human health. Examples of mineral resources used in geomedicine and of their relevant properties, particularly clay/mud and biogenic carbonate sand, are described in the present paper.
\end{abstract}

${ }^{1}$ Centro de Investigação "Minerais Industriais e Argilas" da FCT (Fundação para a Ciência e a Tecnologia) - Universidade de Aveiro, 3810-193 Aveiro, Portugal, cgomes@geo.ua.pt. 


\section{RESUMO: Importância dos minerais na Saúde Humana}

Infelizmente, nos últimos anos a investigação tem dado saliência aos efeitos negativos dos minerais na saúde humana.

Contudo, está bem reconhecido que determinados minerais têm grande importancia para a boa saúde humana, quer fazendo parte a composição de áua potável de nascente e de vegetais e frutos comestiveis, quer incorporados em muitos fármacos depois de submetidos a processamento industrial mais ou menos complexo.

Presentemente, assiste-se ao crescente interesse por tratamentos que utilizam meios naturais, alternativos aos utilizados pela medicina convencional. Trata-se da chamada naturoterapia, que envolve processos e métodos distintos, tais como: fitoterapia, hidroterapia, crenoterapia, termoterapia, argiloterapia, etc.

Quando a naturoterapia envolve minerais ou outros recursos geológicos pode chamar-se geomedicina, uma nova área científica que compreende os fundamentos e as práticas da aplicação dos geomateriaisof que condicionam a saúde humana. De facto, tipos particulares de argila/lama, areia, sal e água de nascente e mineromedicinal, intervêm como condicionadores físicos e químicos na saúde humana. Exemplos de recursos minerais e das suas propriedades relevantes são apresentados nesta comunicação.

\section{INTRODUCTION}

Unfortunately, research in recent years has been mainly addressed to the negative effects of minerals on the human health, and the results of much of this research are being presented at scientific journals and meetings, as is the case of the very recent International Mineralogical Association (IMA) meeting held on September 2002, in Edinburgh.

However, it is well established that some particular minerals, under the form of $\mathrm{Ca}, \mathrm{Mg}, \mathrm{Fe}$, and other trace elements, are of paramount importance for good human health, either being part of the composition of drinkable spring waters and eatable vegetables and fruits, or being incorporated in many pharmacs after being submitted to some degree of industrial processing.

As a matter of fact, man along his existence, has taken advantage of the positive effects on his health, through internal or external applications, of certain specific properties of minerals, such as: adsorption, absorption, specific heat, heat diffusivity, cooling kinetics, chemical composition and chemical dissolution. 


\section{THE PAST}

On an empirical basis, the pre-historical man did utilize clay for therapeutic purposes. The clay plates of Nippur, in Mesopotamia, written down about 2500 years BC (before Christ) had a reference to clay good for the treatment of wounds and to stop hemorragies. In the ancient Egypt, Pharaos doctors used yellow ochre - mixture of clay and iron oxydes/hydroxides - to cure skin wounds and internal affections, due to its antiseptic, absorvent and purifying properties. Clay was used as well in the mummyfication process.

The oldest book known so far, the famous Papyrus Ebers, written down in $1550 \mathrm{BC}$, reports some diseases and mineral based medicines consisting of clays (REINBACHER, 1999).

Within the most famous medicinal clays, "Bolus Armenus" a red clay that occurs inside caves in Cappadocio mountains, in old Armenia and actual Turkey, deserves to be mentioned as well as the so-called "terras" of the Greek islands Lemnos, Chios, Samos, Milos and Kimolos. Within them the "terra sigillata" of Lemnos island deserves a particular mention, because this white astringent and absorbent clay after being prepared and shaped under the form of disks, these were marked or stamped with the goat stamp, the mark of Diana ou Artemis goddess. The clay from Kimolos island was identified as Ca-smectite (ROBERTSON, 1986).

Geophagy, a very old practise, is the deliberated eating by man of earth, soil or clay, and according to WILSON (2002), is still common in certain countries and communities for therapeutic and religious purposes or even to relieve famine.

Geophagy was first referred to by Aristhoteles (in MAHANEY et al., 2000) and is a current practise among mammals, birds, and reptiles. This application used empirically to treat certain internal organic affections, could be explained on a scientific basis by the chemical inertia and the absorbing power of clay minerals.

Geophagy was first referred to by Aristhoteles (in MAHANEY et al., 2000) and is a current practise among mammals, birds, and reptiles. This application used empirically to treat certain internal organic affections, could be explained on a scientific basis by the chemical inertia and the absorbing and adsorbing capacities of clay minerals.

As a rule, clay/mud bears clay minerals, such as kaolinite, illite, smectite, sepiolite, palygorskite, the most frequent among others, associated to non clay minerals, such as quartz, feldspar, mica, calcite, dolomite and goethite, also the most frequent among others.

There are written reports in Greece and Egypt referring the use by man of thermal water. The Etruscs are considered to be the inventors of thermalism. Herodote, Hippocrate and Aristhoteles recommend and discuss the positive effects of thermal water in human health. 
During the roman empire the so-called roman baths have achieved great development and the medicinal virtues of both thermal waters or warmed up spring waters were the object of real cult or veneration. With the end of the roman empire the decadence of thermalism has taken place, and only during the Renaissance the interest for thermalism has been renewed.

In Europe, during the XVIII and XIX centuries, the Thermal Centres have undergone great development becoming since then important industries, both in economic and social terms.

Salt extracted, either from sea water, or from rock salt, the mineral halite being its major component, has been incorporated as a fundamental constituent in human diets, since pre-historic times.

\section{THE PRESENT}

Presently, there is a growing interest on treatments using natural means, alternative to those of the conventional medicine. It is the so-called naturotherapy or naturopathy or Hyppocratic medicine, that involves distinct methodologies, such as: phytotherapy, hydrotherapy, mudtherapy, thermotherapy, homeopathy, etc.

In France, the term crénothérapie corresponds to the therapeutic utilization of spring water in spas, under the form of drink, bath, douche, pulverization, inhalation, and mud-bath.

Whenever naturotherapy involves minerals or other mineral resources we can name it geomedicine. As a matter of fact, geomaterials, such as particular types of clay/mud, sand, rock salt and spring water, intervene both as chemical and physical conditioners in human health.

GOMES and SILVA (2001) introduced the term geomedicine that comprises the fundamentals and practises of the application of geomaterials as conditioners in human health.

Naturopathologists believe that good health depends upon three main factors: structural, biochemical and emotional. Minerals and the other mineral resources referred to would be included in the second group of factors, because biochemical interactions beween them and the human body will take place.

According to GOMES and SILVA (2001) in order to be effective in geomedicine clay/mud needs to exhibit specific qualities, such as: fine granularity, high specific surface area, high specific heat, high adsorbing and absorbing capacities, low cooling rate, high cation exchange capacity, easy handling, as well as pleasant sensation when applied directly onto the skin.

Clays are pelitic or lutitic geomaterials, and particular types of clay/mud are used worldwide, either in Thalassotherapy Centres, or "in situ" in geologic sites located, as a rule, in littoral regions where clays, marls or marly limestones do 
occur, for therapeutic treatments called mudtherapy or peloidtherapy (or pelotherapy, an abbreviate term), generally under the form of both mud baths and hot cataplasms or patches called peloids.

Peloids are made of mixtures of clay or mud and thermal spring water or sea water. They are applied at an initial temperature of around $55{ }^{\circ} \mathrm{C}$ (it should be significantly higher than body temperature), and the application lasts until the temperature decreases to around $36{ }^{\circ} \mathrm{C}$ ). The process proceeds for about 20 minutes, depending upon the characteristics (texture, composition, specific heat and heat diffusiveness) of the clay/mud paste, that should be wrapped up in a permeable tissue, in order to allow the absorption through the skin of the chemical elements fixed reversibly in the clay/mud, based on the establishment of ion gradients and on ion exchange reactions.

Presently, clay/mud being used in many medicinal applications comes, in particular, from deposits formed in certain thermal springs or from deposits formed in shallow seas, highly saline and rich in organic matter, for instance, in Black Sea and Dead Sea.

Clay/mud is applied, either under the form of mud-baths, or under the form of warm cataplasms or patches.

However, is also current the application, either indoors or outdoors, of clays containing carbonates, the so-called finely grained marly clays exhibiting dark grey colour, found in deposits that belong particularly to Upper Cretaceous and Miocene. This is the case, for instance, of some littoral deposits occurring nearby Praia do Meco, Praia da Parede and Praia da Consolação, in the Atlantic coast of Portugal. Presently, the relevant assets of these geomaterials are under study.

Pelitic geomaterials, clays and muds, have been used by man, since the prehistory, in order to improve his health, through external (topically) and internal (orally) applications.

The distinction between clay and mud makes sense, since clay minerals can be scarce or even absent in muds, as is the case of some of the fine muds associated to thermal springs (water temperature around $95^{\circ} \mathrm{C}$ ) deposited inside the calderas of some fumaroles which occur in Vale das Furnas, São Miguel island, Azores, and that consist of amorphous aluminosilicates, K-feldspar, calcite, and alunite. Kaolinite or smectite could be identified in the muds produced by some calderas. In comparative terms, mud bearing smectite is characterized by higher cation exchange capacity and specific surface area than kaolinite bearing mud (TERROSO, et al., 2003).

Also, the same authors referred to found that the thermal springs in calderas yielding muds are of acid-sodium-sulphate displaying $\mathrm{pH}$ values in the range 2.4-2.8. On the other hand, the thermal springs of calderas that do not produce muds are of sodium-bicarbonate-chloride type displaying $\mathrm{pH}$ values in the range 6.3-7.8. Some springs in Vale das Furnas, of acid-sodium-sulpate type, bear much 
iron in solution (20-40 ppm) that by precipitation produces red coloured deposits. Local people use to drink this type of water to fight anaemia.

The muds referred to are locally used in a spa (Centro Termal das Furnas), under the form of cataplasms or patches, particularly for treatments of psoriasis and other dermatological diseases, as well as of arthro-articular affections.

In fact, particular types of clay/mud are still used worldwide for therapeutic treatments, either in thalassotherapy centres existing in some spas or in geologic sites, under the form of cataplasms or mud baths. Generally, these treatments are recommended and applied to arthro-rheumatic, muscular and other inflammatory affections, as well as to dermatological diseases, such as psoriasis, acne and seborrhoea.

Also, some clays and clay minerals have been and are still being taken orally by man, as part of pills, powders or emulsions, in order to act as gastrointestinal protectors, laxatives and antidiarrhoeaics.

Besides, particular types of clays and clay minerals are used in aesthetic medicine as cosmetic products, in order to clean and moisturise the skin, as well as to treat specific dermatological diseases.

Both sedimentary and hydrothermal clays, without or with little previous preparation, are being used as healing materials.

Maturation, that is, the intimate mixing and lasting contact between clay/mud and saline water or thermal spring water, is a preparation currently applied in spas (SÁNCHEZ et al., 2002).

On the other hand, the clay/mud can be engineered by blending distinct types of clay/mud, or by blending the clay/mud with certain other minerals, for instance, particular types of biogenic carbonate sand (GOMES and SILVA, 2001). Also, both the incorporation of certain organic products, for instance, particular types of algae, and additives, such as salts (generally sulphides and sulphates of $\mathrm{Ca}, \mathrm{Mg}, \mathrm{I}, \mathrm{Br}$ ), are currently performed.

Peloids composition can be engineered in order to enhance the relevant properties required for certain functions. Also, peloids can be recycled keeping their specific properties, if these had been previously and properly investigated and identified.

In recent years the number of scientific publications concerned with the use of clays in geomedicine has increased significantly, some of them deserving to be highlighted: FERRAND and YVON (1991), BARBIERI (1996), YVON and FERRAND (1996), Novelli (1996), Veniale \& Setti (1996), Veniale (1997), Veniale et al. (1999), BETTERo et al. (1999), CARA et al. (1996, 1999, 2000a; 2000b), GORGONI et al. (1999), Jobstraibizer (1999), Minguzzi et al. (1999), Veniale (1999), CARA et al. (1999) and SÁNCHEZ et al. (2000a, 2000b).

BECH (1996) published a short review about the historic and technical aspects of clays of medicinal use, and very recently CARRETERO (2002) published an 
updated review dealing with the beneficial effects of clay minerals upon human health.

Besides, clays containing certain minerals are used in cosmetics, as well as in pharmacy particularly as excipients and coadjuvants (fillers, dispersants, lubricants, surfactants). When present in pharmacs, mainly under the form of pills, powders or emulsions, clay minerals act particularly as inert compounds. They can, however, influence the rate of drug release, as well as of drug degradation and elimination.

The following papers on clay applications in pharmacy and cosmectics deserve to be mentioned: BROWNE et al. (1980), HERMOSIN et al. (1981), GALAN et al.(1985), UEDA and HAMAyoshi (1992), LoPEZ-Galindo and IbORRA (1996), Viseras \& LOPEZ-GALINDO (1999), LOPEZ-GALINDO and VisERAS (2000) and VENIALE (2001).

The adsorbent properties of clay minerals - which are phyllosilicates, more precisely hydrated aluminosilicates, whose grain size is generally smaller than $1 \mu \mathrm{m}$ (one micron), and that a global negative electric charge - are responsible for the clay capacity for the reversible retention or adsorption of certain molecules or ions at the surface of their particles. On the other hand, the absorbent properties of some clay minerals (smectite, for instance), allow for the incorporation of certain molecules or ions in their crystalline structures, in a more permanent way.

Clay or mud particles can be smaller than bacteria, and these whenever coated or encapsulated by clay particles lose activity and can be eliminated. Certain clays containing smectite and palygorskite as major mineral components are the most currently applied as healing clays because they display more notoriously the referred to properties.

Direct applications of clay/mud are used in the treatment of skin affections such as psoriasis, seborrohea and acne or under the form of cataplasms in the treatment of rheumatic affections, artropathies and in post-traumatic processes and dislocations.

GOMES and SILVA (2001) found that the blending of bentonite from Serra de Dentro, Porto Santo island, Madeira archipelago, with finely grained biogenic carbonate sand, occurring either on the beach or on the frontal dune of the same island, could yield a product providing the benefits of its individual components.

On the one hand, this type of sand rich in $\mathrm{Ca}, \mathrm{Mg}, \mathrm{Sr}, \mathrm{P}$ and $\mathrm{S}$ can be easily dissolved in a weakly acidic medium, as is the case of the human sweat produced during the traditional sand-bath, currentlly performed, either outdoors in the transition from the beach sand to the frontal dune sand, or indoors in Thalassotherapy Centres. During sand-bath treatment, that could be named psammotherapy, those chemical elements being liberated in the ionic form become available to be absorbed through the skin into the human body. On the other hand, the thermal properties of the clay/sand paste are modified, its cooling rate significantly increases. 
Porto Santo biogenic carbonate sands are composed of very fine grains of calcium carbonate, mainly under the form of calcite, admixed with relatively few finely grained lithic fragments of volcanic rocks. Calcite bears in its structure an abnormally high magnesium content, and aragonite enriched in strontium is an accessory component. Dating by ${ }^{14} \mathrm{C}$ of the biogenic carbonate sands from Porto Santo provided ages in the range $15,000-31,000$ years BP. They were formed during the time span corresponding to the Last Great Glatiation (LGG) that in the northern hemisphere was at its peak about 21,000 years BP, in conditions favourable for formation and growth of reefs consisting mainly of red (rhodophyta) calcareous algae well represented by Lithothamnium sp. on the shallow platforms developed around the island, as well as for their dismantling in relation to sea level changes.

The heat liberated by clay/mud pastes, after being properly warmed up and when in contact with the human body, reduces both articular and muscular inflammations, situation that could be confirmed using the technique named thermography. Simultaneously, the heat favours the opening of skin pores, so it facilitates the absorption into both the extra-cellular and intra-cellular fluids of relevant major and oligoelements, such as: $\mathrm{Si}, \mathrm{Ca}, \mathrm{Mg}, \mathrm{Fe}, \mathrm{P}, \mathrm{S}, \mathrm{Sr}, \mathrm{Zn}$ and $\mathrm{Cu}$, whose effects for the good human health are reckoned in the literature available concerned with human physiology. Cation exchange reactions do take place, based upon an established concentration gradient between the cations that get free from clay/mud, and the cations exsuded from the human body, under the heat action.

The referred to biogenic carbonate sand which occurs in beaches and dunes of Porto Santo island has been used by man for more than one hundred years, on an empirical basis, under the form of sand-baths, to alleviate, with reckoned success, chronic and recurrent pain due to osteo-articular and muscular affections.

Similar sands occur in some other Atlantic islands of the biogeographic Macaronesia archipelago, that comprises Azores, Madeira, Canarias and Cape Verde archipelagos, as well as in islands of the Caribbean sea, and in the Pacific islands of the Coral Sea.

GOMES and SILVA (2001) made an attempt to explain on a scientific basis, emphasizing the specific thermal and microchemical properties, the therapeutic assets of Porto Santo island biogenic carbonate sand. The clinical demonstration

386 of sand-baths positive effects still require much investigation. So far, clinical data corresponding essentially to thermographies and blood tests, have been performed at the "Smerteterapi Klinic", in Oslo. This clinic, specialized in the survey, assessment and treatment of chronic and recurrent pain, carried out the tests on individuals from several groups of Norwegian citizens who have been submitted to medically assisted sand-baths at the Hotel Porto Santo Geomedicine Centre. The results obtained so far confirm the health benefits being achieved, however a thorough scientific understanding of the results is still required. 
Also, GOMES and SILVA (2001) introduced the name "medicinal" agriculture after finding that vegetables and fruits cultivated in Porto Santo biogenic carbonate sandy soils were significantly enriched, comparatively to soils developed on other carbonate rocks, in the chemical elements previously referred to.

Consequently, in the therapies whose positive effects are induced by $\mathrm{Ca}, \mathrm{Mg}$, $\mathrm{Sr}, \mathrm{P}$, and $\mathrm{S}$ in the ionic form, would be possible to provide patients with diets that could include, in a controlled manner, vegetables (tomato, lettuce, carrot, etc.) and fruits (grape, melon, water-melon, etc.) grown up on soils based on biogenic carbonate sands from Porto Santo island.

Smectitic clays, such as bentonites, are the ones more widely used in peloidtherapy or mudtherapy applications due to their high swelling, high plasticity, high specific surface and high ion exchange properties.

Nevertheless, very little is known so far, about the real interaction between clay/mud and the human body, situation that requires much research and assessment based upon adequate clinical tests.

In Europe, it is possible to find pharmacy formulations based upon specific clays, such as kaolin and smectite (more precisely dioctahedral smectite), which provide relief due to their sorbent properties. Kaolin is also part of, for instance, formulations for facial masks as is the case of the toning exfoliating scrub masks.

According to REINBACHER (1999) in USA pharmacies it is sold an anti-diarrhoea pharmac made of about $75 \%$ of palygorskite and in Germany pharmacies for the same effect a pharmac is sold made of about $75 \%$ of kaolin.

It is known that when kaolinite, smectite, palygorskite and sepiolite are incorporated in pharmaceutical and animal feed formulations, due to either the adsorvent or absorvent properties of certain chemical compounds as well as of toxines, bacteria and virus, or due to the protecting coatings of the stomach, bowels and skin. In this last function, clays are utilized in dermatology and cosmetics.

Direct applications of clay/mud are used in the treatment of skin affections such as psoriasis, seborrohea and acne or under the form of cataplasms in the treatment of rheumatic affections, artropathies and in post-traumatic processes and dislocations.

Also, pastes made of clay/mud from thermal springs, containing sulphurous thermal water, green sulphurous algae and vitamins $\mathrm{E}$ and $\mathrm{PP}$ are used in mud face masks recommended as nourishing anti-wrinkle products, as is the case, for instance, of the ones produced in Terme di Répole, Italy.

Also, the most recent developments in molecular biology and biotechnology, as well as in the new field of pharmacogenetics, have prooved that any human being bears unique genetic and physiologic characteristics, so two persons can react differently to the same pharmac.

Things, however, can become complicated, but at the same time interesting in scientific terms, if an individual patient requires a particular pharmac made to measure. 
It is also possible that individual patients react differently to treatments involving natural means. It could even happen that a certain treatment shows no effect at all. In case of possible negative effects, and in comparative terms, damages due to treatment with natural products would not be as serious as those that rely on conventional pharmacs.

The clay mineral smectite is a common constituent of clay pastes used worldwide in geomedicine. Illite, illite/smectite mixed layers and kaolinite are other clay minerals which are currently present in clay pastes.

Smectite, kaolinite, palygorskite and talc are currently part of several pharmaceutical formulations, acting either as active principles or as excipients.

Rarely, synthetic clay minerals are used for therapeutic purposes. An exception is the equivalent of hectorite named "Laponite S" used as gelifying product in cosmetic.

Salt from rock salt is another mineral whose health benefits have been recognised, for instance, in respiratory affections, as is the case of the saline aerosol developed in salt mines, such as the Royal Mine of Wiliczka, in Poland, that is part of the Natural and Cultural World Heritage of UNESCO. A salt bloc bearing inside a cavity, where an electric lamp could be adapted, releases by hydration (slow dissolution produced by the air moisture) ions, such as $\mathrm{Na}^{+1}, \mathrm{Cl}^{-1}, \mathrm{I}^{-1}$, which are considered to cause beneficial effects in the respiratory system.

Spring waters, particularly the so-called mineromedicinal waters, of varied thermal and chemical categories, hyperthermal, mesothermal, hypothermal and fluorinated, alkaline, bicarbonated, sulphurous, ferrous, etc., have been used since the roman times, either under the form of bathing or drinking, for the treatment of dermatologic, gastric, respiratory, rheumatic, muscular and circulatory affections. In Europe there are more than one thousand of spas.

The properties of spring waters or mineral waters, either thermal or not, have been the object of great advances during the $\mathrm{XX}$ century leading to the progressive development of an important scientific area named hydrochemistry that has taken advantage of the availability of new analytical facilities, methodologies and techniques.

Spring waters can bear a gaseous phase (such as, $\mathrm{CO}_{2}, \mathrm{~N}, \mathrm{SO}_{2}, \mathrm{H}_{2} \mathrm{~S}, \mathrm{He}$, radon and rare gases), and oligoelements in solution (such as, $\mathrm{B}, \mathrm{Br}, \mathrm{I}, \mathrm{F}, \mathrm{Si}, \mathrm{Li}, \mathrm{Al}, \mathrm{Sr}$, $\mathrm{Ba}, \mathrm{Fe}, \mathrm{Cu}, \mathrm{As}, \mathrm{Se}, \mathrm{REE}$ and radioactive elements), which presently can be the object of fine analysis. Also, isotopes $\left({ }^{18} \mathrm{O},{ }^{14} \mathrm{C}\right.$, deuterium and titrium) analysis 388 provides information about the origin and age of spring waters or mineral waters.

In Portugal, a thorough study of mineromedicinal waters, in particular, due to their paramount importance for hydrothermalism, a promising industry in socio-economic terms (presently there are in Portugal 34 active spas), deserves much consideration and development. Both water fine physico-chemical characterization and its reckoned clinical effects will be the basic support for the required renewal of infrastructures of the spas, as well as for the introduction of new products and methods. 


\section{REFERENCES}

ASTM (1984) - American Society for Testing Materials, Annual Book of ASTM Standards. Water Environmental Technology, v, 11.01.

BARBIERI, P. (1996) - Validitá terapeutica dei fanghi delle Terme di Salice. Atti Conv. Argille Curative (Veniale, F., ed.), Gruppo Italiano AIPEA, Salice Terme PV (Italy), Tipografia Trabella, Milano, 13-15.

BECH, J. (1996) - Aspectos históricos y técnicos de las arcillas de uso medicinal. In: IX Simp. Grupo Especializado de Cristalografia. La cristalografia y la industria farmaceutica. Ed Reales Soc. Esp. Física y Química. Univ. Granada, pp. 15-17.

BETTERo, A et al. (1999) - Aspetti reologici e tensiometrici di matrici fangose di impiego termali e cosmetico. Proposta di un protocollo per la loro qualificazione. Atti Simposio «Argille per fanghi peloidi termali e per trattamenti dermatologici e cosmetici», Montecatini Terme. Mineralogica e Petrografica Acta XLII, 277-286.

BROWNE, J. et al. (1980) - Characterization and adsorptive properties of pharmaceutical grade clays. J. Pharm. Sci., 69, 816-823.

CARA, S. et al. (1996) - Possibilità di impiego dele bentoniti sarde nel campo delle argille sanitarie. Atti Conv. Argille Curative (Veniale, F., ed.), Gruppo Italiano AIPEA, Salice Terme PV (Italy), Tipografia Trabella, Milano, 103-117.

CARA, S. et al. (2000a) - The bentonites in pelotherapy: chemical, mineralogical and technological properties of materials from Sardinia deposits (Italy). Applied Clay Science, $16,117-124$.

CARA, S. et al. $(2000 \mathrm{~b})$ - The bentonites in peelotherapy: thermal properties of clay pastes from Sardinia (Italy). Applied Clay Science, 16, 125-132.

CARRETERO, M. I. (2002) - Clay minerals and their beneficial effects upon human health: a review. Applied Clay Science, 21, 155-163.

FERRAND, T. and Yvon, J. (1991) - Thermal properties of clay pastes for pelotherapy. Applied Clay Science, 6, 21-38.

GALÁN, E. et al. (1985) - Minerales utilizados en la industria farmaceutica. Bol. Soc. Esp. Min., 369-378.

Gomes, C. and SiLva, J. (2001) - Beach sand and bentonite of Porto Santo Island: Potentialities for applications in Geomedicine. Gomes, C. \& Silva, J. (editors), O Liberal, Câmara de Lobos, Madeira, 60 p.

GoRGONI, C. et al. (1999) - Comoposizione, radiottivitá, mineralogia e reologia dei fanghi delle Salse Emiliane. Abstracts Book of Simposio "Argille per fanghi peloidi termali e per trattamenti dermatologici e cosmetici”, Montecatini Terme, Gruppo Italiano AIPEA.

Hermosin, M. et al. (1981) - Sepiolite, a potential excipient for drugs subject to oxidative degradation. J. Pharm. Sci., 70, 189-192.

HUNT, D. T. E. and WILSON, A L. (1986) - The chemical analysis of water. General principles and techniques. The Royal Society of Chemistry, $683 \mathrm{p}$.

JobSTRAIBIZER, P. (1999) - Definizione mineralogica e chimica del fango termali e per trattamenti dermatologici e cosmetici, Montecatini Terme. Mineral. Petrogr. Acta XLII, 317-327.

LOPEZ-GALINDO, A and IBORRA, C. (1996) - Usos farmaceuticos de arcillas especiales (sepiolita e palygorskita). Atti Conv. "Argille Curative", (Veniale, F. ed.), Gruppo Italiano AIPEA, Salice Terme (PV), Italy. Tipografia Trabella, Milano, 45-53.

LOPÉZ-GALINDO, A and VISERAS, C. (2000) - Pharmaceutical applications of fibrous clays (sepiolite and palygorskite) from some circum-mediterranean deposits. In: Gomes, C. 
S. F. (ed.), $1^{\text {st }}$ Latin American Clay Conference, Funchal, Madeira, Associação Portuguesa de Argilas (APA), v.1, 258-270.

MAHANEY, W. C. et al. (2000) - Mineral and chemical analyses of soils eaten by humans in Indonesia. Nternational Journal of Environmental Health Research, 10, 93-109.

MINGUZZI, V. et al. (1999) - Le argille curative in uso negli stabilimenti termali emilianoromagnoli: verifica della comosizione e delle propietá. Atti Simposio “ argille per fanghi peloidi termali e per trattamenti dermatologici cosmetici”. Montecatini Terme. Miner. Petrogr. Acta, XLII, 287-298.

Novelli, G. (1996) - Applicazioni medicali e igieniche delle bentoniti. Atti Conv. "Argille Curative", (Veniale, F. ed.), Gruppo Italiano AIPEA, Salice Terme (PV), Italy. Tipografia Trabella, Milano.

NovelLi, G. (2000) - Bentonite: a clay over the centuries. Incontri Scientifici. V Corso di Formazione " Metodi di Analisi di Materiali Argillosi. Gruppo Italiano aipea, 263-304.

REINBACHER, W.R. (1999) - A brief history of clay in medicine. Clay Minerals Society News, $11,1,22-23$.

SÁNCHEZ, C. et al. (2000a) - Aplicaciones terapéuticas de las arcillas de Santa Cruz de Mudela (Ciudad Real). In: Pascual, J (ed.), Integración Ciencia-Tecnologia de las Arcillas en el Contexto Tecnológico- Social del Nuevo Milenio. Sociedad Española de Arcillas, 31-40.

SÁNCHEZ, C. et al. (2000b) - Behaviour of matured illitic-smectitic clays for pelotherapy. In: Gomes, C. S. F. (ed.), $1^{\text {st }}$ Latin American Clay Conference, Funchal, Madeira, Associação Portuguesa de Argilas (APA), v.2, 317-321.

SÁNCHEZ, C. et al. (2002) - The effect of maturation upon the mineralogical and physicochemical properties of illitic-smectitic clays for pelotherapy. Clay Minerals, 37, 457-463.

Summa, V. and TATEO, F. (1998) - The use of pelitic raw materials in thermal centres: mineralogy, geochemistry, grain size and leaching test: examples from the Lucania area (southern Italy). Applied Clay Science, 12, 403-417.

Terroso, D. et al. (2003) - Muds deposited by fumaroles in Vale das Furnas, S. Miguel island, Azores archipelago: properties relevant for their use in mudtherapy. Euroclay 2003, $10^{\text {th }}$ Conference of the European Clay Groups Association, Modena, Italy, 269-270 pp.

TORRESCANI, C. (1990) - Utilizzo del fango termale sulfureo nel tratattamento della cute seborreica. Cosmesi Derm., 30, 59-71.

UEDA, H. and HAMAYYOSHI, M.(1992) - Sepiolite as a deodorant material: an ESR study of its properties. J. Materials Sci., 27, 4997-5002.

Veniale, F. and Setti, M. (1996) - L'argilla di Pontestura (AL): Potenzialità d'impiego nella formulazione di fanghi peloid. Atti Conv. "Argille Curative", (Veniale, F. ed.), Gruppo Italiano AIPEA, Salice Terme (PV), Tipografia Trabella, Milano,139-145.

VISERAS, C. and LÓPEZ-GALINDO, A. (1999) - Pharmaceutical applications of some spanish clays (sepiolite, palygorskite, bentonite): some preformulation studies. Applied Clay Science 14, 69-82.

WILSON, M. J. (2002) - A review of clay mineralogical and other characteristics of geophagic materials ingested by animals and man. Communication presented at a memorial meeting for Dr. Maria Angeles Vicente at the University of Salamanca, organized by the Sociedad Española de Arcillas.

YVON, J. and FERRAND, T. (1996) - Preparation ex-situ de peloides. Proprietés thermiques, mecaniques et d'exchange. Atti Conv. "Argille Curative", (Veniale, F. ed.), Gruppo Italiano AIPEA, Salice Terme (PV), Tipografia Trabella, Milano, 67-78. 